\title{
THE EFFECTIVENESS OF A SCHOOL-BASED INTERVENTION FOR THE TREATMENT OF IRON DEFICIENCY ANEMIA
}

Eliana Pereira Vellozo ${ }^{1} \cdot$, Maria Aparecida Zanetti Passos ${ }^{2} \mathbb{*}$, Francisco Plácido

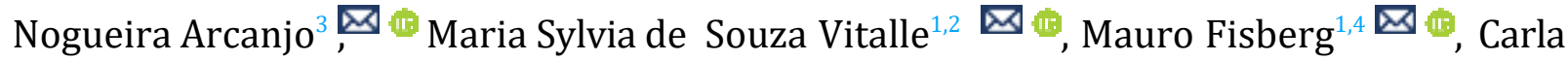
Cristina Enes ${ }^{5} \cdot$, André Luiz Monezi Andrade $^{5} \cdot$, Sheila Rejane Niskier $^{6} \cdot$, Aline de Piano Ganen $^{7}$, Peter Richard Hall ${ }^{8}$ and Josefina Aparecida Pellegrini Braga ${ }^{1,9}$

${ }^{1}$ Adolescent Medicine Sector, Department of Pediatrics, Universidade Federal de São Paulo / Escola Paulista de Medicina,

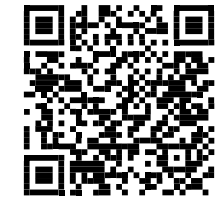

São Paulo, São Paulo, Brazil

${ }^{2}$ Postgraduate Program in Education and Health in Childhood and Adolescence, Universidade Federal de São Paulo / Escola

Paulista de Medicina, São Paulo, Brazil

${ }^{3}$ Department of Health Science, Universidade Federal do Ceará, Campus Sobral, Ceará, Brazil

${ }^{4}$ Instituto Pensi, Fundação José Luiz Setúbal, Hospital Infantil Sabará, São Paulo, Brazil

${ }^{5}$ Center of Life Science, Pontifical Catholic University of Campinas, Campinas, Brazil

${ }^{6}$ Department of Pediatrics, Universidade Federal de São Paulo, São Paulo, Brazil

Department of Nutrition, São Camilo University Center, São Paulo, Brazil

${ }^{8}$ Faculty of Medicine, Centro Universitário INTA, Sobral, Brazil

${ }^{9}$ Hematology Sector, Department of Pediatrics, Universidade Federal de São Paulo / Escola Paulista de Medicina, São Paulo,

Brazil

Received 1 May 2021

Revised 15 May 2021

Published 31 May 2021

CorrespondingAuthor

Eliana Pereira Vellozo, eliana.vello

zo@unifesp.br

DOI 10.29121/

granthaalayah.v9.i5.2021.3919

Funding: This research received no specific grant from any funding agency in the public, commercial, or not-for-profit sectors.

Copyright: (C) 2021 The Author(s). This is an open access article distributed under the terms of the Creative Commons Attribution License, which permits unrestricted use, distribution, and reproduction in any medium, provided the original author and source are credited.

\section{ABSTRACT}

Background: In Brazil, iron deficiency anemia is considered a public health problem, which has a direct impact on the process of child growth and development. To assess the impact of a powdered supplement added to food preparations, on hemoglobin ( $\mathrm{Hb}$ ) levels and other hematimetric parameters in children.

Method: This study is a double-blind, community-controlled clinical trial conducted in education centers in the northeast of Brazil. In this trial, food preparations were offered with a powdered supplement, enriched with iron (intervention) and control (no supplementation), Monday through Friday, for 60 days. Two biochemical evaluations were performed to determine $\mathrm{Hb}$, hematocrit (Ht), mean corpuscular volume and ferritin levels before and after the intervention.

Results: For participants in the 6- to 59-month age range, we identified an increase in mean $\mathrm{Hb}$ concentrations and other hematimetric parameters. In the 5- to 11-year age group, there was a significant increase in both groups for $\mathrm{Hb}$ and $\mathrm{Ht}$ values, and mean $\mathrm{Hb}$ concentration was significantly greater in the intervention group $(12.25 \pm 0.76$ vs. $11.93 \pm 0.94$, p<.0035). In the 12 - to 14 year-olds, all variables analyzed presented an increase. 
Conclusions: This school-based intervention effectively increased $\mathrm{Hb}$ concentrations other hematimetric parameters and reduced the prevalence of anemia in children and adolescents.

Keywords: Anemia, Iron Deficiency, Child Nutrition, Iron Supplements, Hemoglobins

\section{INTRODUCTION}

Worldwide, it is estimated that almost two billion people have anemia, and $27 \%$ to $50 \%$ of the population has iron deficiency (ID) Brazil (2019); Kassebaum and Gbd (2013); Pediatria (2018); WHO (2017). In Brazil, iron deficiency anemia (IDA) is considered a public health problem, and in some regions, it is the most prevalent nutritional deficiency among children under the age of five years, which has a direct impact on the process of child growth and development, both physical, cognitive, and behavioral Brazil (2019); Pediatria (2018). However, statistical data vary widely, with results indicating that 40 to $50 \%$ of the children studied are affected by this condition Pediatria (2018), with the highest prevalence being in the northern and northeastern regions of the country Kassebaum and Gbd (2013); Pediatria (2018).

Although IDA is a condition that affects different socioeconomic classes, it ends up affecting more frequently populations with lower household income per capita, with less schooling, with greater difficulty in accessing basic services such as sanitation and electricity, and in situations of food and nutrition insecurity de Castro Morais et al. (2014); Kassebaum and Gbd (2013); Oliveira et al. (2010); Pediatria (2018); WHO (2017).

Faced with the problem of IDA in Brazil, there are some programs and policies in progress in the country that aim to control and prevent it, among them are the fortification of wheat and corn flours, as outlined in the National Iron Supplementation Program and the NutriSUS Strategy Brazil (2019).

Considering the relevance of further investigations on the issue, this study aims to assess the impact of a powdered supplement, enriched with iron, added to food preparations, on hemoglobin ( $\mathrm{Hb}$ ) levels and other hematimetric parameters in children and adolescents enrolled in early childhood centers and schools, compared with a control group (CG).

\section{MATERIALS AND METHODS}

\subsection{STUDY DESIGN, PARTICIPANTS, AND LOCATION}

This is a double-blind, community-controlled study that enrolled 2368 participants to evaluate the impact of a powdered supplement, enriched with iron, added to food preparations, on $\mathrm{Hb}$ levels and other hematimetric parameters, in the municipality of Cabo de Santo Agostinho, State of Pernambuco, in the northeast of Brazil. 
The protocol for the parent study was approved by the Research Ethics Committee of the Universidade Federal de São Paulo - Escola Paulista de Medicina (UNIFESP / EPM), protocol number 1040/07. All students aged 6 months to 14 years from the early education centers and schools were invited to participate in our study. The children and parents or legal guardians were consented / assented prior to participation in the study. Exclusion criteria were schoolchildren with chronic diseases; history of blood transfusion in the previous three months; those with $\mathrm{Hb}<9.5 \mathrm{~g} / \mathrm{dL}$ at the initial evaluation (who were referred to specific outpatient treatment), students already using iron supplementation and parents' refusal to participate. Medical support was available upon request. After intervention, anemic children were referred for treatment.

The study was conducted in 10 municipal early education centers and schools which were randomized into 2 groups: the IG and the CG, each with 5 municipal early education centers and schools. For this study, we only considered infants and children aged six months to 14 years with IDA, defined according to World Health Organization (WHO) criteria. WHO (2011)

\subsection{INTERVENTION}

In this study, for the IG, single-dose sachets of the powdered supplement, enriched with iron (according to each age range) were mixed into the child's individual portion of food immediately before consumption (Table 1 ). The intervention was administered Monday through Friday and lasted for 60 days, beginning, and ending on the same date for all participants.

Table 1 Food preparations in the intervention group.

\begin{tabular}{lllll}
\hline $\begin{array}{l}\text { Type of educa- } \\
\text { tion center }\end{array}$ & Age range & $\begin{array}{c}\text { Number of } \\
\text { supplemented } \\
\text { meals offered } \\
\text { / day }\end{array}$ & $\begin{array}{c}\text { Daily per capita } \\
\text { consumption } \\
\text { (g) by } \\
\text { group }\end{array}$ & $\begin{array}{c}\text { Daily iron supple- } \\
\text { mentation (mg) for } \\
\text { every 100g of food }\end{array}$ \\
offered
\end{tabular}

\subsection{DATA COLLECTION}

Two biochemical evaluations were performed to determine $\mathrm{Hb}$, hematocrit (Ht), mean corpuscular volume (MCV) and ferritin levels before and at the end of the intervention. In addition, anthropometric measurements (weight and height) were taken, according to standard techniques as proposed by Lohman et al (1988), ${ }^{8}$ to calculate the Body Mass Index (BMI). Members of the study team who collected outcome data were blinded to the different interventions. 


\subsection{STATISTICAL ANALYSIS}

Statistical procedures were performed based on the intention to treat. Excel 2010 programs and SPSS software version 23.0 for Windows (SPSS Inc.; Chicago, IL, USA) were used to tabulate and analyze the data.

According to the initial characteristics, the means and standard deviations of the continuous variables and the absolute and relative frequencies of the categorical variables were calculated. All variables were subjected to the Kolmogorov-Smirnov test to verify the normal distribution of data. Participants were stratified by age (according to the criteria established by the WHO for the identification of IDA) WHO (2011) to facilitate the analysis of the results: $6 \geq 59$ months, $5 \geq 11$ years, $12 \geq 14$ years. During the intervention, the change in age of the participants was taken into consideration, and they were reallocated accordingly.

A comparative analysis of the biochemical parameters, age, weight, height and BMI was performed between the groups before the intervention, using the test for independent samples; within and between groups after the intervention using the t-test for independent samples (by intention to treat); the differences between the initial and final means $(\Delta)$ of the study variables were calculated; and the comparative analysis of these means was performed using the t test for independent samples. A comparative analysis for the presence / absence of IDA according to the Hb values before and after the intervention was performed using Fisher's exact test (twotailed). The number needed to treat (NNT) was calculated to verify the impact of the intervention on $\mathrm{Hb}$ levels. The level of significance was adjusted to $5 \%(\mathrm{p}<0.05)$ in all tests.

\section{RESULTS}

In this subgroup analysis, a total of 461 infants and children aged six months to 14 years presented IDA, with 216 children in the IG and 245 children in the CG.

Table 2 Comparative analysis of study variables according to age group before the intervention.

\begin{tabular}{|c|c|c|c|c|c|c|}
\hline Age range & Variables & $\mathbf{n}$ & Intervention group & $\mathbf{n}$ & Controle group & $95 \% \mathrm{CI}$ \\
\hline & & & Mean \pm SD & & Mean \pm SD & \\
\hline \multirow[t]{8}{*}{ 6-59 months } & Age (years) & 5 & $4.32 \pm 0.74$ & 18 & $4.53 \pm 0.25$ & $-0.63,0.21$ \\
\hline & Hemoglobin (g/dL) & 5 & $10.32 \pm 0.80$ & 18 & $10.13 \pm 0.73$ & $-0.59,0.96$ \\
\hline & Hematocrit (\%) & 5 & $28.40 \pm 7.27$ & 18 & $31.64 \pm 1.53$ & $-6.88,0.39$ \\
\hline & MCV (fL) & 5 & $75.20 \pm 6.94$ & 18 & $75.83 \pm 6.49$ & $-7.55,6.28$ \\
\hline & Ferritin (ng/mL) & 5 & $54.88 \pm 27.96$ & 17 & $26.61 \pm 11.66$ & $10.99,45.55$ \\
\hline & Weight (kg) & 4 & $18.33 \pm 5.67$ & 15 & $19.31 \pm 5.12$ & $-7.18,5.21$ \\
\hline & Height (m) & 5 & $1.07 \pm 0.16$ & 15 & $1.11 \pm 0.13$ & $-0.21,0.12$ \\
\hline & BMI & 5 & $15.79 \pm 2.62$ & 15 & $15.44 \pm 1.42$ & $-1.65,2.36$ \\
\hline \multirow[t]{3}{*}{$5 \geq 11$ years } & Age (years) & 179 & $7.98 \pm 1.96$ & 214 & $7.52 \pm 1.99$ & $0.06,0.85$ \\
\hline & Hemoglobin (g/dL) & 179 & $10.79 \pm 0.54$ & 214 & $10.77 \pm 0.62$ & $-0.10,0.13$ \\
\hline & Hematocrit (\%) & 179 & $32.80 \pm 2.69$ & 214 & $32.79 \pm 2.32$ & $-0.49,0.51$ \\
\hline
\end{tabular}




\begin{tabular}{|c|c|c|c|c|c|c|}
\hline \multicolumn{7}{|c|}{ Table 2 continued } \\
\hline & MCV (fL) & 179 & $78.96 \pm 5.60$ & 214 & $78.50 \pm 6.17$ & $-0.72,1.63$ \\
\hline & Ferritin (ng/mL) & 176 & $44.14 \pm 30.65$ & 209 & $42.22 \pm 24.37$ & $-3.59,7.44$ \\
\hline & Weight (kg) & 171 & $27.81 \pm 9.68$ & 202 & $26.20 \pm 9.03$ & $-0.30,3.52$ \\
\hline & Height (m) & 171 & $1.27 \pm 0.14$ & 202 & $1.25 \pm 0.14$ & $-0.00,0.05$ \\
\hline & BMI & 171 & $16.68 \pm 3.02$ & 202 & $16.31 \pm 2.53$ & $-0.19,0.94$ \\
\hline \multirow[t]{8}{*}{$12 \geq 14$ years } & Age (years) & 32 & $12.53 \pm 0.32$ & 13 & $12.44 \pm 0.39$ & $-0.13,0.32$ \\
\hline & Hemoglobin $(\mathrm{g} / \mathrm{dL})$ & 32 & $11.35 \pm 0.48$ & 13 & $11.33 \pm 0.72$ & $-0.35,0.39$ \\
\hline & Hematocrit (\%) & 32 & $34.48 \pm 1.79$ & 13 & $34.97 \pm 1.52$ & $-1.63,0.65$ \\
\hline & MCV (fL) & 32 & $80.63 \pm 5.51$ & 13 & $80.00 \pm 7.94$ & -3.54 .4 .79 \\
\hline & Ferritin (ng/mL) & 32 & $37.71 \pm 23.31$ & 13 & $39.20 \pm 36.05$ & -19.71 .16 .72 \\
\hline & Weight (kg) & 32 & $38.69 \pm 11.78$ & 13 & $35.66 \pm 7.55$ & -4.11 .10 .17 \\
\hline & Height (m) & 32 & $1.44 \pm 0.11$ & 13 & $1.43 \pm 0.12$ & -0.06 .0 .09 \\
\hline & BMI & 32 & $18.31 \pm 3.70$ & 13 & $17.40 \pm 2.75$ & -1.39 .3 .20 \\
\hline
\end{tabular}

All numbers are absolute. MCV = mean corpuscular volume. BMI = Body mass index. SD =- Standard deviation. Confidence interval for the mean difference. $¥$ Calculated using the $t$ test for independent samples.

Table 2 Presents the initial characteristics of the participants, with a significant difference observed for ferritin in the $6 \geq 59$-month age range (IG $54.88 \pm 27.96$ vs. CG $26.61 \pm 11.66 \mathrm{ng} / \mathrm{mL}, \mathrm{p}=.003$ ); and in the age group of $5 \geq 11$ years, the participants in the IG were older (IG $7.98 \pm 1.96$ vs. CG $7.52 \pm 1.99$ years, $p=.023$ ). At baseline, the distribution of participants according to age group shows a predominance in the $5 \geq 11$-year age range, with 179 students in the IG and 214 in the CG. There were no significant differences for other variables analyzed (Table 2 ).

During the study it must be acknowledged that the children aged, and consequently, the number of children in each age group also changed; at the end of the intervention, distribution was as follows: in the $6 \geq 59$-month age range there were 3 participants in the IG and 16 in the CG; in the $5 \geq 11$-year age range - 164 participants in the IG and 197 in the CG; and in the in the 12 $\geq 14$-year age range - 49 participants in the IG and 32 in the CG.

In the comparative analysis of the biochemical parameters and BMI before and after the intervention, in the 6 $\geq 59$-month age range, an increase in $\mathrm{Hb}$ and $\mathrm{Ht}$ was observed in both groups, however these increases were only significant in the CG, $\mathrm{p}=.002$ and $<.0001$, respectively. In this same age group, a significant difference in the final values was detected between the groups for ferritin, IG $63.47 \pm 34.53$ vs. CG $32.23 \pm 14.58 \mathrm{ng} / \mathrm{mL}, \mathrm{p}=.0247$.

During the study it must be acknowledged that the children aged, and consequently, the number of children in each age group also changed; at the end of the intervention, distribution was as follows: in the $6 \geq 59$-month age range there were 3 participants in the IG and 16 in the CG; in the $5 \geq 11$-year age range - 164 participants in the IG and 197 in the CG; and in the in the 12 $\geq 14$-year age range - 49 participants in the IG and 32 in the CG.

In the comparative analysis of the biochemical parameters and BMI before and after the intervention, in the $6 \geq 59$-month age range, an increase in $\mathrm{Hb}$ and $\mathrm{Ht}$ was observed in both groups, however these increases were only significant in the CG, 
$\mathrm{p}=.002$ and $<.0001$, respectively. In this same age group, a significant difference in the final values was detected between the groups for ferritin, IG $63.47 \pm 34.53 \mathrm{vs.} \mathrm{CG}$ $32.23 \pm 14.58 \mathrm{ng} / \mathrm{mL}, \mathrm{p}=.0247$.

In the 5 $\geq 11$-year age group, there was a significant increase in both groups for $\mathrm{Hb}$ and $\mathrm{Ht}$ values $(\mathrm{p}<.0001)$, and mean $\mathrm{Hb}$ concentration was significantly greater in the IG compared with the CG in the analysis between the groups. (IG $12.25 \pm 0.76$ vs. GC $11.93 \pm 0.94, p=.0035)$. Still in this same age group, the IG showed a significant increase for the MCV at the end of the intervention, from $78.96 \pm 5.60$ to $80.68 \pm 6.04$ $\mathrm{fL}, \mathrm{p}=.0107$. In the 12- to 14-year age range, there was a significant increase in $\mathrm{Hb}$ and $\mathrm{Ht}$ in the IG and in the CG, MCV value showed a significant increase in the IG, from $80.63 \pm 5.51$ to $83.74 \pm 5.50 \mathrm{fL}, \mathrm{p}=.0282$ (Table 3 ).

To better visualize the results, an analysis of the differences between the means $(\Delta)$ of the biochemical parameters and BMI was performed after the intervention according to age group. Only in the 5- to 11-year age range, a significant result was identified, there was a greater absolute increase in mean $\mathrm{Hb}$ concentrations in the IG when compared to the CG, $1.41 \pm 0.81$ vs. $1.19 \pm 0.97 \mathrm{~g} / \mathrm{dL}, \mathrm{p}=.0485$. No statistical significance was identified for any other variable in the comparison between groups (Table 4 ).

The presence / absence of IDA before and after the intervention was determined using Hb concentrations according to the WHO cutoff points. WHO (2011) At the beginning of the study, anemia was present in $100 \%$ of the participants, and there was a reduction in both groups in all age ranges. For preschoolers between 6 and 59 months, the reduction was not significant, in the IG 5 children were anemic at the beginning of the study, and only 1 at the end of the intervention, in CG 18 participants were anemic at the beginning of the study, falling to 3 at the end. For the schoolchildren aged five to 11 years, there was a significant reduction in the prevalence of IDA in both groups ( $\mathrm{IG}=9.52 \%$ vs. $\mathrm{CG}=26.40 \%, \mathrm{p}<.0001)$; and the reduction in the IG was significantly greater than in the CG ( $\mathrm{p}=.0005)$. For the adolescents, aged 12-14 years, a significant reduction in the prevalence of anemia was noted only in the IG (19.35\%, p=.0108) (Table 5 ).

In this study, the IG was compared with the CG to identify a favorable or adverse outcome (absence or presence of anemia). In the six to 59-month age range, the adverse result was present in $33.33 \%$ of the children in the IG and $25.00 \%$ in the $\mathrm{CG}$, showing that the participants were not benefited by the intervention $(\mathrm{NNH}=12)$. However, for the schoolchildren aged 5 to 11 years, the adverse outcome was present in $9.52 \%$ of participants in the IG and $26.40 \%$ in the CG, the difference, the reduction in absolute risk (RAR) was 16.88\% (95\% CI 7.60, 26.15), and the NNT was 6. The intervention was also beneficial for adolescents (12 to 14 years old), the adverse result was present in $19.35 \%$ of the students in the IG, and $28.00 \%$ in the CG, RAR = 8,65\% (95\% CI 13.79, 31.08), and the NNT was 12 (Table 6).

Although acceptance was not studied directly, there was no direct or indirect evidence of a detectable difference in acceptability of the food in the IG compared with 
Table 3 Comparative analysis of biochemical parameters and BMI according to age group before and after the intervention, and between groups, by intention to treat.

\begin{tabular}{|c|c|c|c|c|c|c|}
\hline \multirow{4}{*}{$\begin{array}{l}\text { Age } \\
\text { range }\end{array}$} & \multirow[t]{4}{*}{ Variable } & \multicolumn{2}{|l|}{ Intervention group } & \multicolumn{2}{|l|}{ Control group } & \multirow{3}{*}{$\begin{array}{l}\text { Between } \\
\text { groups at the } \\
\text { end of the } \\
\text { intervention } \\
\text { p-value } \neq\end{array}$} \\
\hline & & Before After & & Before After & p- & \\
\hline & & \multicolumn{3}{|c|}{ Mean $\pm S$ Mean $\pm S$ value $\neq$ Mean $\pm S D$ Mean $\pm S$ va } & & \\
\hline & & $(95 \% \mathrm{CI})$ & & $(95 \% \mathrm{CI})$ & & \\
\hline \multirow[t]{10}{*}{$\begin{array}{l}6 \geq 59 \\
\text { months }\end{array}$} & $\begin{array}{l}\mathrm{Hb} \\
(\mathrm{g} / \mathrm{dL})\end{array}$ & $10.32 \pm 011.30 \pm 0$ & .11 & $11.33 \pm 0$ & .0 & .95 \\
\hline & & \multicolumn{2}{|l|}{$(-2.26,0.30)$} & $(-1.78,-0.62)$ & & \\
\hline & Ht (\%) & $28.40 \pm 734.13 \pm 0$ & .24 & $35.63 \pm 2$ & $<$ & .31 \\
\hline & & \multicolumn{2}{|l|}{$(-16.37,4.90)$} & $(-5.42,-2.54)$ & & \\
\hline & $\begin{array}{l}\text { MCV } \\
(\mathrm{fL})\end{array}$ & $75.20 \pm 675.67 \pm 7$ & .93 & $76.83 \pm 4$ & .65 & .73 \\
\hline & & \multicolumn{2}{|l|}{$(-13.26,12.33)$} & $(-5.43,3.43)$ & & \\
\hline & $\begin{array}{l}\text { Ferritin } \\
\text { (ng/mL) }\end{array}$ & $54.88 \pm 263.47 \pm 3$ & .71 & $26.61 \pm 11.32 .23 \pm 1$ & .26 & .0247 \\
\hline & & \multicolumn{2}{|l|}{$(-62.75,45.58)$} & $(-15.62,4.39)$ & & \\
\hline & BMI & $15.79 \pm 214.56 \pm 0$ & .57 & $15.37 \pm 1$ & .92 & .51 \\
\hline & & \multicolumn{2}{|l|}{$9-4.30,6.77)$} & $(-1.33,1.47)$ & & \\
\hline \multirow[t]{10}{*}{$\begin{array}{l}5 \geq 11 \\
\text { years }\end{array}$} & $\begin{array}{l}\mathrm{Hb} \\
(\mathrm{g} / \mathrm{dL})\end{array}$ & $10.79 \pm 012.25 \pm 0$ & $<.0001$ & $11.93 \pm 0$ & $<$ & .0035 \\
\hline & & \multicolumn{2}{|l|}{$(-1.60,-1.31)$} & $(-1.32,-0.99)$ & & \\
\hline & Ht (\%) & $32.80 \pm 237.55 \pm 2$ & $<.0001$ & $37.44 \pm 2$ & $<$ & .73 \\
\hline & & \multicolumn{2}{|l|}{$(-5.34,-4.16)$} & $(-5.18,-4.12)$ & & \\
\hline & $\begin{array}{l}\text { MCV } \\
(\mathrm{fL})\end{array}$ & $78.96 \pm 580.68 \pm 6$ & .0107 & $79.53 \pm 6$ & .14 & .14 \\
\hline & & \multicolumn{2}{|l|}{$(-3.05,-0.40)$} & $(-2.40,0.35)$ & & \\
\hline & $\begin{array}{l}\text { Ferritin } \\
\text { (ng/mL) }\end{array}$ & $44.14 \pm 347.33 \pm 2$ & .35 & $42.22 \pm 24.43 .42 \pm 2$ & .66 & .22 \\
\hline & & \multicolumn{2}{|l|}{$(-9.88,3.50)$} & $(-6.56,4.15)$ & & \\
\hline & BMI & $16.68 \pm 316.82 \pm 3$ & .71 & $16.70 \pm 2$ & .19 & .76 \\
\hline & & \multicolumn{2}{|l|}{$(-0.89,0.61)$} & $(-0.98,0.19)$ & & \\
\hline $\begin{array}{l}12 \geq 14 \\
\text { years }\end{array}$ & $\begin{array}{l}\mathrm{Hb} \\
(\mathrm{g} / \mathrm{dL})\end{array}$ & $11.35 \pm 012.58 \pm 1$ & $<.0001$ & $12.29 \pm 0$ & .0 & .23 \\
\hline & & $(-1.65,-0.84)$ & & $(-1.48,-0.45)$ & & \\
\hline & Ht (\%) & $34.48 \pm 138.34 \pm 2$ & $<.0001$ & $38.47 \pm 2$ & $<$ & .85 \\
\hline & & $(-5.08,-2.63)$ & & $-4.94,-2.06$ & & \\
\hline & $\begin{array}{l}\text { MCV } \\
(\mathrm{fL})\end{array}$ & $80.63 \pm 583.74 \pm 5$ & .0282 & $84.04 \pm 6$ & .11 & .86 \\
\hline & & $(-5.89,-0.34)$ & & $(-9.04,0.96)$ & & \\
\hline & $\begin{array}{l}\text { Ferritin } \\
\text { (ng/mL) }\end{array}$ & $37.71 \pm 240.05 \pm 1$ & .65 & $39.20 \pm 36.40 .72 \pm 2$ & .89 & .91 \\
\hline & & $-12.65,7.96$ & & $(-22.76,19.73)$ & & \\
\hline & BMI & $18.31 \pm 318.43 \pm 3$ & .89 & $18.73 \pm 3$ & .20 & .74 \\
\hline & & $(-1.93,1.68)$ & & $(-3.40,0.73)$ & & \\
\hline
\end{tabular}

All numbers are absolute. Hemoglobin $=\mathrm{Hb}$. Hematocrit $=\mathrm{Ht}$. MCV = mean corpuscular volume. $\mathrm{BMI}=$ Body mass index. SD =- Standard deviation. 95\%CI = 95\% Confidence interval for the mean difference. $\neq$ Calculated using the $t$ test for independent samples. 
Table 4 Comparative analysis of the differences between the means $(\Delta)$ of the biochemical parameters and BMI after the intervention according to age group.

\begin{tabular}{|c|c|c|c|c|c|c|c|}
\hline \multirow[t]{2}{*}{ Age range } & \multirow[t]{2}{*}{ Variable } & \multicolumn{2}{|c|}{$\begin{array}{l}\text { Intervention } \\
\text { group }\end{array}$} & \multicolumn{2}{|c|}{$\begin{array}{l}\text { Control } \\
\text { group }\end{array}$} & \multirow[t]{2}{*}{$95 \% \mathrm{CI}$} & \multirow[t]{2}{*}{$\begin{array}{l}\text { p- } \\
\text { value } \neq\end{array}$} \\
\hline & & $\mathbf{n}$ & $\Delta \pm$ SD & $\mathbf{n}$ & $\Delta \pm$ SD & & \\
\hline \multirow[t]{5}{*}{$\begin{array}{l}6 \geq 59 \\
\text { months }\end{array}$} & $\begin{array}{l}\text { Hemoglobin } \\
(\mathrm{g} / \mathrm{dL})\end{array}$ & 3 & $0.90 \pm 0.66$ & 12 & $1.14 \pm 1.01$ & $-1.58,1.10$ & .70 \\
\hline & Hematocrit (\%) & 3 & $2.83 \pm 1.88$ & 12 & $4.12 \pm 2.12$ & $-4.19,1.62$ & .36 \\
\hline & MCV (fL) & 3 & $4.00 \pm 3.46$ & 12 & $2.67 \pm 3.52$ & $-3.57,6.24$ & .57 \\
\hline & $\begin{array}{l}\text { Ferritin } \\
(\mathrm{ng} / \mathrm{mL})\end{array}$ & 3 & $4.77 \pm 39.74$ & 12 & $5.98 \pm 15.56-3$ & $\begin{array}{l}30.73, \\
28.30\end{array}$ & .93 \\
\hline & BMI & 2 & $0.05 \pm 0.43$ & 6 & $\begin{array}{l}- \\
0.52 \pm 1.01\end{array}$ & $-1.32,2.44$ & .49 \\
\hline \multirow[t]{10}{*}{$5 \geq 11$ years } & $\begin{array}{l}\text { Hemoglobin } \\
(\mathrm{g} / \mathrm{dL})\end{array}$ & 126 & $.41 \pm 0.81$ & 1251 & $.19 \pm 0.97$ & $0.00,0.45$ & .0485 \\
\hline & Hematocrit (\%) & 126 & $.06 \pm 3.64$ & 1254 & $.66 \pm 3.03$ & $-0.43,1.23$ & .35 \\
\hline & MCV (fL) & 126 & $.13 \pm 2.34$ & 1251 & $.78 \pm 2.82$ & $-0.29,0.99$ & .28 \\
\hline & $\begin{array}{l}\text { Ferritin } \\
\text { (ng/mL) }\end{array}$ & 125 & $3.33 \pm 28.46$ & 116 & $3.40 \pm 22.33$ & $-6.59,6.46$ & .98 \\
\hline & BMI & 105 & $.34 \pm 1.22$ & 1050 & $.68 \pm 2.38$ & $-0.85,0.18$ & .20 \\
\hline & $\begin{array}{l}\text { Hemoglobin } \\
\text { (g/dL) }\end{array}$ & 31 & $1.41 \pm 1.08$ & 25 & $1.31 \pm 1.13$ & $-0.50,0.69$ & .75 \\
\hline & Hematocrit (\%) & 31 & $3.98 \pm 2.35$ & 25 & $5.35 \pm 5.00$ & $-3.40,0.67$ & .18 \\
\hline & MCV (fL) & 31 & $2.19 \pm 3.05$ & 25 & $2.76 \pm 0.93$ & $-1.84,0.70$ & .37 \\
\hline & $\begin{array}{l}\text { Ferritin } \\
(\mathrm{ng} / \mathrm{mL})\end{array}$ & 31 & $\begin{array}{l}- \\
1.25 \pm 18.57\end{array}$ & 25 & $\begin{array}{l}- \\
7.33 \pm 25.111\end{array}$ & $\begin{array}{l}-5.62 \\
7.79\end{array}$ & .30 \\
\hline & BMI & 36 & $0.72 \pm 1.18$ & 25 & $0.38 \pm 2.48$ & $-0.61,1.29$ & .47 \\
\hline
\end{tabular}

All numbers are absolute. $\Delta=$ differences between the means. $\mathrm{MCV}=$ mean corpuscular volume. $\mathrm{BMI}=$ Body mass index. SD =- Standard deviation. 95\% CI = 95\% Confidence interval for the mean difference. $\neq$ Calculated using the $\mathrm{t}$ test for independent samples.

Table 5 Comparative analysis of the presence of anemia according to hemoglobin values according to age group before and after the intervention, and between groups.

\begin{tabular}{|c|c|c|c|c|c|c|c|}
\hline \multirow[t]{2}{*}{$\begin{array}{l}\text { Age } \\
\text { range }\end{array}$} & \multicolumn{3}{|c|}{$\begin{array}{l}\text { Intervention } \\
\text { group }\end{array}$} & \multirow{2}{*}{$\begin{array}{l}\text { Control } \\
\text { group } \\
\text { Before } \\
\text { Cases/- } \\
\text { Total }\end{array}$} & \multirow[b]{2}{*}{$\begin{array}{l}\text { After } \\
\text { Cases/- } \\
\text { Total }\end{array}$} & \multirow[b]{2}{*}{$\begin{array}{l}\text { p- } \\
\text { value }\end{array}$} & \multirow{2}{*}{$\begin{array}{l}\text { p-value } \neq \\
\text { between the groups (at } \\
\text { the end of the } \\
\text { intervention) }\end{array}$} \\
\hline & $\begin{array}{l}\text { Before } \\
\text { Cases/- } \\
\text { Total }\end{array}$ & $\begin{array}{l}\text { After } \\
\text { Cases/- } \\
\text { Total }\end{array}$ & $\begin{array}{l}\text { p- } \\
\text { value }\end{array}$ & & & & \\
\hline $\begin{array}{l}6-59 \\
\text { months }\end{array}$ & $\begin{array}{c}5 / 5 \\
(100.0)\end{array}$ & $\begin{array}{l}1 / 3 \\
(33.33)\end{array}$ & .38 & $\begin{array}{l}18 / 18 \\
(100.0)\end{array}$ & $\begin{array}{l}3 / 12 \\
(25.00)\end{array}$ & .05 & $>.99$ \\
\hline $\begin{array}{l}5 \geq 11 \\
\text { years }\end{array}$ & $\begin{array}{l}179 / 179 \\
(100.0)\end{array}$ & $\begin{array}{l}12 / 126 \\
(9.52)\end{array}$ & $<.00$ & $\begin{array}{l}214 / 214 \\
(100.0)\end{array}$ & $\begin{array}{l}33 / 125 \\
(26.40)\end{array}$ & $<.00$ & .0005 \\
\hline $\begin{array}{l}12 \geq 143 \\
\text { years }\end{array}$ & $\begin{array}{l}32 / 32 \\
(100.0)\end{array}$ & $\begin{array}{l}6 / 31 \\
(19.35)\end{array}$ & .0108 & $\begin{array}{l}13 / 13 \\
(100.0)\end{array}$ & $\begin{array}{l}7 / 25 \\
(28.00)\end{array}$ & .07 & .53 \\
\hline
\end{tabular}

All numbers are absolute, with respective frequencies given in parentheses. $\ddagger$ Calculated using Fisher’s exact test (two-tailed). 
Table 6 Comparative analysis of the number needed to treat (NNT) according to age group.

\begin{tabular}{|lllllll}
\hline Age range & $\begin{array}{l}\text { Adverse } \\
\text { outcome } \\
\text { (\%) }\end{array}$ & ARR & ARI & IC 95\% & NNT & NNH \\
\hline $\begin{array}{l}\text { Intervention } \\
\text { group }\end{array}$ & $\begin{array}{l}\text { Control } \\
\text { group }\end{array}$ & $\mathbf{( \% )}$ & $\mathbf{( \% )}$ & & \\
\hline $6-59$ & 33.33 & 25.00 & & 8.33 & -50.37, & \\
months & & 26.40 & 16.88 & $7.60,26.15$ & 6 & \\
\hline $5 \geq 11$ years & 9.52 & 28.00 & 8.65 & -13.79, & 12 \\
\hline $\begin{array}{l}12 \geq 14 \\
\text { years }\end{array}$ & 19.35 & & & 31.08 & \\
\hline
\end{tabular}

Adverse outcome $=$ participants remained anemic at the end of the study. ARR $=$ Absolute risk reduction. $\mathrm{ARI}=$ Absolute risk increase. $95 \% \mathrm{CI}=95 \%$ confidence interval. $\mathrm{NNT}=$ Number needed to treat. $\mathrm{NNH}=$ Number needed to harm.

the CG. The powdered supplement enriched with iron did not alter the color or taste of the food to be consumed. No complaints were received from participants or parents / guardians in either group; there were no dropouts after the intervention had begun.

\section{DISCUSSION}

The objective of this study to assess the impact of a powdered supplement, enriched with iron, added to food preparations, on Hb levels and other hematimetric parameters in children and adolescents enrolled in early childhood centers and schools, compared with a CG. For participants in the 6 to 59 months age range, there was an increase in mean $\mathrm{Hb}$ concentrations in both groups, with a greater increase in the CG. The small number of children analyzed in this age range $(n=3)$ may have contributed to the non-significant increase in the IG. Among participants aged 5 to 11 years, there was an increase in $\mathrm{Hb}$ and $\mathrm{Ht}$ in both groups, however, the rise in mean $\mathrm{Hb}$ concentration $(\Delta)$ was significantly greater in the IG $(1.41 \pm 0.81 \mathrm{~g} / \mathrm{dL}$ vs. $1.19 \pm 0.97$, $\mathrm{p}=.0485)$. The NNT for the treatment of anemia in this age group was 6 . In the older age range (12-14 years), all variables analyzed in both groups presented an increase; this increase was considered significant for $\mathrm{Hb}, \mathrm{Ht}$ and MCV in the IG, and $\mathrm{Hb}$ and $\mathrm{Ht}$ in the CG. However, there were no significant differences between the groups. The NNT for the treatment of anemia in this age group was 12.

Pre- and school-age children are at greater risk for IDA, the global prevalence of anemia in this age range is 47.4 and $25.4 \%$, respectively WHO (2008). In Brazil, researchers have reported that approximately one-fifth of children under the age of five years were anemic Brazil (2009). The consequences of IDA vary greatly, which has been associated with inhibited growth, low birth weight, poor psychomotor and cognitive development, compromised immunity, and increased infant morbidity and mortality Beard (2001); Domellöf et al. (2013); WHO (2001). At the United Nations summit in 2000, the Millennium Development Goals made a call to improve child 
nutrition UN (2015). Treatment for IDA usually involves iron fortification or supplementation and making dietary changes Man et al. (2021). In this context, several studies have been conducted to verify the effectiveness of different fortification and supplementation programs.

Arcanjo et al. (2019) evaluated the impact of NutriSUS micronutrient fortification for the prophylaxis and treatment of IDA. This cluster-randomized clinical trial was conducted with 130 infants aged 12-36 months during a period of 12 weeks. At the end of the intervention, the authors reported a significant increase in mean $\mathrm{Hb}$ concentrations $(0.5 \mathrm{~g} / \mathrm{dL})$, and a significant decrease in anemia prevalence (from $29.9 \%$ to $7.5 \%$ ). Another randomized, double-blind controlled trial was performed in Western Europe to investigate the effect of a micronutrient fortified young-child formula compared to cow's milk on iron and vitamin D status, in 318 children aged 1-3 years. After a 20-week intervention, there was a significant reduction in the number of anemic children in the young-child formula group. However, there was no significant difference between the groups for mean change in Hb Akkermans et al. (2017). For this age range, these findings are in line with those presented in the current study an increase in mean $\mathrm{Hb}$ concentrations and a decrease in the prevalence of anemia.

Duque et al. (2014) conducted a randomized, double-blind clinical trial in 200 children, aged 5 to 13 years, who showed low iron stores without anemia, in Mexico City. In this study, the authors had as aim to compare the effect of ferrous sulfate and iron bis-glycinate chelate on serum ferritin concentration. Both interventions lasted 12 weeks and provided a significant increase in serum ferritin levels; this effect persisted for 6 months after the intervention. A community-based randomized controlled trial, conducted in the Kirti Nagar slums of West Delhi with 446 mildly and moderately anemic volunteer adolescent girls (aged 11-18 years), had as objective to assess and compare the impact of weekly iron folic acid supplementation with or without vitamin B12 on the prevalence of anemia, Hb concentration, serum ferritin, folic acid, and vitamin B12. Results from this study showed that weekly iron folic acid supplementation (with or without vitamin B12) significantly improved iron status and reduced anemia prevalence Bansal et al. (2016).

In Sri Lanka, a trial was conducted with 821 schoolchildren aged 12-16 years. This study had as objective to evaluate the effectiveness of combined iron and zinc over the iron or zinc-only supplementation. At the end of the intervention, in the irononly supplementation group there was a mean $\mathrm{Hb}$ increase of $18.2 \mathrm{~g} / \mathrm{l}$, and in the iron+zinc group a mean $\mathrm{Hb}$ increase of $11.0 \mathrm{~g} / \mathrm{l}$. Furthermore, for the prevalence of anemia there was a significant reduction in the iron-only and iron+zinc groups, from 70.3 to $14.5 \%$ and 64.8 to $19.3 \%$, respectively Hettiarachchi et al. (2008). In the present study, we identified a $1.41 \mathrm{~g} / \mathrm{dL}$ increase in mean Hb concentrations for participants aged 5 to 11 years and 12 to 14 years; and a significant reduction in the prevalence of anemia, for participants aged 5 to 11 years in the IG, from 100 to $9.52 \%$, and for those aged 12 to 14 years, from 100 to $19.35 \%$ after the intervention. 
Our intervention was insufficient to bring about changes in BMI, probably due to the short duration of the study (60 days). To date, few studies have addressed the effects of micronutrient fortification on BMI. One such study conducted by Goyle (2012), in India with 107 adolescent girls aged 10 to 16 years, assessed the effect of supplementation of biscuits with and without micronutrients on weight and height. This controlled clinical trial resulted in significant weight gains of 1.85 and $2.00 \mathrm{~kg}$ in the control and experimental groups, respectively. In summary, the intervention with biscuits with and without micronutrients resulted in significant improvements in weight gain and BMI.

Supplementation with multiple micronutrient powders has also been the focus of systematic reviews. De-Regil et al. (2011) performed a review to assess the effects and safety multiple micronutrient powders for the fortification of foods in children under two years of age. Eight trials were included in the review with a total of 3748 participants in low-income countries with high prevalence rates of anemia. Multiple micronutrient powders reduced anemia by $31 \%$ and ID by $51 \%$ when compared to control or placebo. Suchdev et al. (2020) conducted a meta-analysis to assess the effects and safety of multiple micronutrient powders. Twenty-nine studies conducted in low- and middle-income countries with 33,147 children aged 6 to 23 months were included. The authors concluded that the home fortification of foods with multiple micronutrient powders was an effective intervention for the reduction of IDA and ID in children under the age of 2 years.

Currently, the WHO defends the use of multiple micronutrient powders for the fortification of foods. These powders are intended to increase the mineral and vitamin intakes of infants and schoolchildren. For this, a guideline was published to help Member States and their partners achieve the Sustainable Development Goals, which establishes global targets for maternal, infant and young child nutrition WHO (2016).

Regarding the present study, some limitations need to be acknowledged and addressed. Many confounding factors may affect the outcome of $\mathrm{Hb}$ concentrations and the prevalence of anemia, such as illness, inadequate dietary habits, periods of rapid growth, etc. Secondly, the period of intervention was short (60 days), a longer period may have presented more significant results. In the $6 \geq 59$-month age range, one major limitation of our findings is the statistical insignificance of the results due to the small number of participants, 5 at baseline, and 3 at the end of the intervention. In addition, the iron dosage in the powdered supplement refers to the value offered to the participants and not necessarily to the amount ingested. Finally, the intervention was conducted only on school days (excluding weekends and holidays) and food intake was not recorded on weekends. Nevertheless, this is one of the few studies to tackle IDA with multiple micronutrient powders for the fortification of foods in such a wide age range (from six months to 14 years). 


\section{CONCLUSIONS}

In conclusion, this powdered supplement, enriched with iron, added to food preparations effectively increased $\mathrm{Hb}$ concentrations and other hematimetric parameters, and reduced the prevalence of anemia in children and adolescents enrolled in childhood centers and schools. In populations where anemia is considered a public health problem, we recommend the fortification of food with iron-containing micronutrient powders to improve iron status and reduce anemia prevalence. Furthermore, future studies should be conducted to identify the long-term effects of this kind of intervention on other parameters such as growth, cognitive and motor development, attention span, and resistance to infection.

\section{ACKNOWLEDGEMENTS}

The authors wish to thank the employees at the early education centers and schools in the municipality of Cabo de Santo Agostinho who assisted in the collection of data, and the children and parents/guardians for their patience and valuable assistance.

\section{REFERENCES}

Akkermans, M. D., Eussen, S. R., van der Horst-Graat, J. M., van Elburg, R. M., van Goudoever, J. B., \& Brus, F. (2017). A micronutrient-fortified young-child formula improves the iron and vitamin D status of healthy young European children: a randomized, double-blind controlled trial. The American Journal of Clinical Nutrition, 105(2), 391399. Retrieved from https://dx.doi.org/10.3945/ajcn.116.136143 10.3945/ajcn.116 .136143

Arcanjo, F. P. N., da Costa Rocha, T. C., Arcanjo, C. P. C., \& Santos, P. R. (2019). Micronutrient Fortification at Child-Care Centers Reduces Anemia in Young Children. Journal of Dietary Supplements, 16(6), 689-698. Retrieved from https://dx.doi.org/10.1080/ 19390211.2018.1474987 10.1080/19390211.2018.1474987

Bansal, P. G., Toteja, G. S., Bhatia, N., Vikram, N. K., \& Siddhu, A. (2016). Impact of weekly iron folic acid supplementation with and without vitamin B12 on anaemic adolescent girls: a randomised clinical trial. European Journal of Clinical Nutrition, 70(6), 730-737. Retrieved from https://dx.doi.org/10.1038/ejcn.2015.215 10.1038/ejcn.2015.215

Beard, J. L. (2001). Iron Biology in Immune Function, Muscle Metabolism and Neuronal Functioning. The Journal of Nutrition, 131(2), 568S-580S. Retrieved from https://dx.doi .org/10.1093/jn/131.2.568s 10.1093/jn/131.2.568s

Brazil. (2009). Estatística e Informação em Saúde. Brasília: Ministério da Saúde. Centro Brasileiro de Análise e Planejamento. Pesquisa Nacional de Demografia e Saúde da Criança e da Mulher - PNDS 2006: Dimensões do processo reprodutivo e da saúde da criança. Série $G$.

Brazil. (2019). Author. Retrieved from https://portaldeboaspraticas.iff.fiocruz.br/atencao -crianca/carencias-nutricionais-anemia-ferropriva/

de Castro Morais, D., Dutra, L. V., do Carmo Castro Franceschini, S., \& Priore, S. E. (2014). Insegurança alimentar e indicadores antropométricos, dietéticos e sociais em estudos brasileiros: uma revisão sistemática. Ciência \& Saúde Coletiva, 19(5), 1475-1488. 
Retrieved from https://dx.doi.org/10.1590/1413-81232014195.13012013 10.1590/ 1413-81232014195.13012013

De-Regil, L. M., Suchdev, P. S., Vist, G. E., Walleser, S., \& Peña-Rosas, J. P. (2011). Home fortification of foods with multiple micronutrient powders for health and nutrition in children under two years of age. Cochrane Database Syst Rev(9), 8959-8959.

Domellöf, M., Thorsdottir, I., \& Thorstensen, K. (2013). Health effects of different dietary iron intakes: a systematic literature review for the 5 th Nordic Nutrition Recommendations. Food \& Nutrition Research, 57(1), 21667-21667. Retrieved from https://dx.doi.org/ 10.3402/fnr.v57i0.21667 10.3402/fnr.v57i0.21667

Duque, X., Martinez, H., Vilchis-Gil, J., Mendoza, E., Flores-Hernández, S., Morán, S., Navarro, F., Roque-Evangelista, V., Serrano, A., \& Mera, R. M. (2014). Effect of supplementation with ferrous sulfate or iron bis-glycinate chelate on ferritin concentration in Mexican schoolchildren: a randomized controlled trial. Nutrition Journal, 13(1), 71-71. Retrieved from https://dx.doi.org/10.1186/1475-2891-13-71 10.1186/1475-2891 $-13-71$

Goyle, A. (2012). Effect of micronutrient fortified biscuit supplementation on the weight, height and BMI of adolescent girls. Coll Antropol, 36(2), 573-579.

Hettiarachchi, M., Liyanage, C., Wickremasinghe, R., Hilmers, D. C., \& Abrams, S. A. (2008). The efficacy of micronutrient supplementation in reducing the prevalence of anaemia and deficiencies of zinc and iron among adolescents in Sri Lanka. European Journal of Clinical Nutrition, 62(7), 856-865. Retrieved from https://dx.doi.org/10.1038/sj.ejcn .1602791 10.1038/sj.ejcn.1602791

Kassebaum, N. J., \& Gbd. (2013). Anemia Collaborators. The Global Burden of Anemia. Hematol Oncol Clin North Am, 30(2), 247-308.

Lohman, T. G., Roche, A. F., \& Martorell, R. (1988).

Man, Y., Xu, T., Adhikari, B., Zhou, C., Wang, Y., \& Wang, B. (2021). Iron supplementation and iron-fortified foods: a review. Critical Reviews in Food Science and Nutrition, 122. Retrieved from https://dx.doi.org/10.1080/10408398.2021.1876623 10.1080/ 10408398.2021.1876623

Oliveira, J. S., de Lira, P. I. C., Maia, S. R., de Souza Sequeira, L. A., de Araújo de Amorim, R. C., \& Filho, M. B. (2010). Insegurança alimentar e estado nutricional de crianças de Gameleira, zona da mata do Nordeste brasileiro. Revista Brasileira de Saúde Materno Infantil, 10(2), 237-245. Retrieved from https://dx.doi.org/10.1590/s1519 -38292010000200011 10.1590/s1519-38292010000200011

Pediatria, S. B. D. (2018). Retrieved from https://www.sbp.com.br/fileadmin/user_upload/ 21019f-Diretrizes_Consenso_sobre_anemia_ferropriva-ok.pdf.Accessed

Suchdev, P. S., Jefferds, M. E. D., Ota, E., da Silva Lopes, K., \& De-Regil, L. M. (2020). Home fortification of foods with multiple micronutrient powders for health and nutrition in children under two years of age. Cochrane Database of Systematic Reviews, 2(2), 8959-8959. Retrieved from https://dx.doi.org/10.1002/14651858.cd008959 .pub3 10.1002/14651858.cd008959.pub3

UN. (2015). We can end poverty: Millennium development goal and beyond. Retrieved from https://www.un.org/millenniumgoals/bkgd.shtml.Accessed

WHO. (2001). Iron deficiency anaemia: assessment, prevention, and control. A guide for programme managers. Geneva: World Health Organization. Retrieved from https://www.who.int/nutrition/publications/en/ida_assessment_prevention _control.pdf.Accessed

WHO. (2008). Worldwide prevalence of anaemia 1993-2005 WHO Global Database on 
Anaemia. Geneva: World Health Organization. Retrieved from https://apps.who.int/ iris/bitstream/handle/10665/43894/9789241596657_eng.pdf?ua=1

WHO. (2011). Haemoglobin concentrations for the diagnosis of anaemia and assessment of severity. Vitamin and Mineral Nutrition Information System. Geneva: World Health Organization. Retrieved from https://www.who.int/vmnis/indicators/haemoglobin .pdf.Accessed

WHO. (2016). . WHO guideline: use of multiple micronutrient powders for point-of-use fortification of foods consumed by infants and young children aged 6-23 months and children aged 2-12 years. Geneva: World Health Organization. Retrieved from https:// www.who.int/publications/i/item/9789241549943.Accessed

WHO. (2017). Nutritional anaemias: tools for effective prevention and control. Geneva: World Health Organization. World Health Organization. Re.trievedAccessed February 14, 2021, from https://apps.who.int/iris/bitstream/handle/10665/259425/ 9789241513067-eng.pdf 